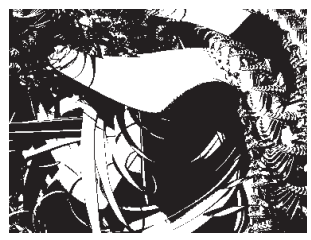

doi:10.5559/di.20.2.10

\title{
STRUKTURA VRIJEDNOSNIH ORIJENTACIJA I HIJERARHIJA VREDNOTA UČENIKA STRUKOVNIH ŚKOLA
}

Nataša VLAH

Diečii vrtić Rijeka, Rijeka

Darko LONČARIĆ, Sanja TATALOVIĆ VORKAPIĆ

Učiteljski fakultet, Rijeka

UDK: 316.752-057.874:17.022.1

303.722.2:316.752

Izvorni znanstveni rad

Primljeno: 3. 6. 2009.

Oslanjajući se na prethodna istraživanja hijerarhije vrednota i zastuplienosti vrijednosnih orijentacija adolescenata, postavili smo dva cilja istraživanja: (1) utvrditi vrijednosne orijentacije reprezentativne podgrupe srednjoškolaca srednjih stručnih škola Primorsko-goranske regije i (2) dati doprinos istraživanju faktorske strukture i pouzdanosti Skale vrijednosnih orijentacija (Franc i sur., 2002.) na takvu uzorku. Na stratificiranom su grupnom uzorku od 760 učenika $(M=17,5$ godina; $S D=1,22$; $41,2 \%$ učenica) u deset škola prikuplieni podaci te je eksploratornim metodama provjerena komponentna i faktorska struktura skale, pouzdanost skale i utvrđena hijerarhija vrijednosti i vrijednosnih orijentacija. Rezultati upućuju na to da se komponentna struktura upitnika primijenjenog na učenike strukovnih škola znatno razlikuje od strukture koje su na reprezentativnim uzorcima učenika svih srednjih škola utvrdili autori skale. Faktorskom analizom izdvojena su dva značajna faktora: (1) samoostvarujuća i konvencionalna vrijednosna orijentacija i (2) hedonistička vrijednosna orijentacija. Na vrhu hijerarhije vrijednosti učenika jesu liubav, skladan život, obiteli, prijatelji i bliski prijateljski odnosi. Implicirana je potreba dogradnje i rekonstrukcije ovog upitnika u primjeni u stručnim srednjim školama.

Ključne riječi: vrijednosne orijentacije, učenici strukovnih škola 
Ljudske vrijednosti pripadaju posebnoj kategoriji psiholoških konstrukata koji su u pravom smislu riječi multidisciplinarni, pa se shodno tomu uspješno istražuju u nizu socijalno znanstvenih disciplina (Braithwaite i Scott, 1991.; Mayton i sur., 1994.; Rokeach i Ball-Rokeach, 1989.; Seligman i sur., 1996.). Osim toga, vrijednosti imaju još jedno neuobičajeno svojstvo: relevantne su na obje razine, i na mikrorazini ili individualnoj i na makrorazini ili socijalno/institucionalnoj (Mayton i sur., 1994.). Stoga je sasvim razumljivo da su važan i neizostavan dio niza socijalno aktualnih tema, kao što su rasizam, politička ponašanja, društvena pravda, društvene promjene itd., što je uvelike obuhvaćeno Rokeachovim istraživanjima (1973., 1979., 1982.). Ovaj je autor, osim S. H. Schwartza (1999.), dao najveći doprinos u definiranju i operacionalizaciji vrednota kao poželjnih ciljeva i vodećih načela u životu koje se razlikuju po važnosti (Rokeach, 1973.).

Najčešće su vrednote definirane kao trajna vjerovanja koja utječu na izbor određenoga načina ponašanja (Rokeach, 1973.; Schwartz, 1994.). Nastaju kao rezultat socijalizacije, pa je zato izrazito važno da se $u$ istraživanju strukture vrijednosnoga sustava uzimaju u obzir obilježja društveno strukturiranog iskustva i kulturne pozadine (Schwartz, 2006.), stavova i ponašanja (Schwartz, 1996.). Premda postoje podjele među autorima glede određenja razlika između vrednota i stavova (Franc i sur., 2002.), većina njih slaže se oko toga da shvaćanje vrednota kao uzroka stavova i ponašanja proizlazi iz pretpostavljene motivacijske osnove vrednota, prema kojoj vrednote kognitivno predstavljaju osnovne ljudske potrebe (Homer i Kahle, 1988.; Rohan i Zanna, 2001.; Schwartz i Bilsky, 1990.). Vezano uz to, konceptualna definicija koja prevladava u literaturi obuhvaća 5 aspekata koji obilježavaju vrednote kao: a) vjerovanja, b) poželjna krajnja stanja ili vrste ponašanja, c) procese koji nadilaze specifične situacije, d) kriterije za usmjeravanje izbora ili evaluacije ponašanja, e) elemente koji se razlikuju po relativnoj važnosti u sustavu vrijednosnih prioriteta (Schwartz i Bilsky, 1987., 1990.).

Posebno je zanimljiv dominirajući sustav vrijednosti kod mladih ljudi, koji se može (in)direktno dovesti u vezu s raznim vrstama društveno (ne)poželjnih i (ne)prihvatljivih ponašanja (Ajduković, 1989.; Romero i sur., 2001.). S obzirom na prijašnja, ne toliko brojna, istraživanja hijerarhije vrednota mladih i vrijednosnih orijentacija u Hrvatskoj (Čulig i sur., 1982.; Franc i sur., 2002.; Ivičić i sur., 2007.; Mandarić, 2000.; Radin, 1988., 1990., 2002.), bilo je zanimljivo provjeriti hijerarhiju vrijednosti i zastupljenost vrijednosnih orijentacija u adolescenata. Pritom se ponajprije referiramo na podatke o vrijednostima i vrijednosnim orijentacijama koji su prikupljeni na reprezenta- 
DRUŠ. ISTRAŽ. ZAGREB GOD. 20 (2011), BR. 2 (112)

STR. $479-493$

VLAH, N., LONČARIĆ, D., TATALOVIĆ VORKAPIĆ, S.: STRUKTURA.

$\rightarrow$ SLIKA 1

Strukturno-sukcesivni odnos između uvierenja, vriiednosti, namiera i ponašanja prema Pennington (1997.) tivnim uzorcima srednjoškolaca 1998. godine $(\mathrm{N}=2823$, Franc i sur., 2002.) te 2006. godine ( $N=876$, Ivičić i sur., 2007.). Godine 1998 . ispitano je $24,5 \%$ polaznika gimnazija i $75,5 \%$ polaznika ostalih srednjih škola, a 2006. godine $22,9 \%$ polaznika gimnazija i 71,5\% polaznika stručnih škola. U oba je slučaja primijenjena Skala vrijednosnih orijentacija, koja mjeri 18 vrednota, tj. tri stila vrijednosnih orijentacija: konvencionalni, hedonistički i samoostvarujući (Franc i sur., 2002.; Ivičić i sur., 2007.).

Istraživači su u oba istraživanja potvrdili postavljenu hipotezu o tome da se hijerarhija vrednota i zastupljenost vrijednosnih orijentacija adolescenata zbog karakteristika stabilnosti, trajnosti i univerzalnosti temeljnih vrednota ne razlikuju bitno $\mathrm{u}$ odnosu na one utvrđene u Hrvatskoj i drugim zemljama (Franc i sur., 2002.; Ivičić i sur., 2007.), pa se slažu s rezultatima prijašnjih istraživanja (Ajduković, 1989.; Čulig i sur., 1982.; Mandarić, 2000.; Ule i sur., 2000.). S vremenskim odmakom, no uz uzlazni trend zanimanja za vrednote mladih u Hrvatskoj, bilo je korisno ispitati hijerarhiju i zastupljenost vrijednosnih orijentacija kod polaznika strukovnih škola u Primorsko-goranskoj županiji. Naš interes za isključivo učenike srednjih strukovnih škola proizlazi iz nekih dosadašnjih spoznaja o specifičnostima ponašanja upravo tih učenika $u$ odnosu na njihove vršnjake koji pohađaju gimnazijske programe. Primjerice, prema Bouillet i sur. (2005.), Ministarstvo znanosti, obrazovanja i športa provelo je potkraj školske godine 2003./2004. opsežno istraživanje "Nasilje u školama", pri čemu su utvrđivani opseg i obilježja nasilničkoga ponašanja kod učenika u osnovnoj školi, gimnaziji, stručnoj četverogodišnjoj i stručnoj trogodišnjoj školi. Ponašanje učenika procjenjivali su razrednici $(\mathrm{N}=845$ razrednika) te je dobiveno da se po raznolikosti i učestalosti nasilničkoga ponašanja statistički značajno ističu srednje stručne četverogodišnje i trogodišnje škole. S obzirom na društvenu opasnost takva ponašanja, smatrali smo da bi bilo vrijedno pobliže upoznati neka obilježja specifične populacije.

Za razumijevanje ponašanja pojedinca važno je poznavanje širega sklopa vrednota i vrijednosnih orijentacija dotične populacije, koje je taj pojedinac pripadnik. Pennington je (1997.) prikazao strukturalno-sukcesivni odnos uvjerenja i vrednota sa stavovima koji potom determiniraju namjeru ponašanja (Slika 1).

\section{UVJERENJA.... \\ STAVOVI.... NAMJERE.... PONAŠANJE \\ VREDNOTE...}

Dakle, ponašanje učenika može biti povezano s njihovim vrijednostima. Stoga smo željeli utvrditi strukturu vrijednosnih orijentacija i hijerarhiju vrednota upravo učenika strukovnih škola. 
DRUŠ. ISTRAŽ. ZAGREB GOD. 20 (2011), BR. 2 (112)

STR. $479-493$

VLAH, N., LONČARIĆ, D. TATALOVIĆ VORKAPIĆ, S.: STRUKTURA

\section{METODA}

\section{Sudionici}

(4) TABLICA 1

Naziv škole, apso-

lutni broj i postotak sudionika
Na tako definiranoj populaciji bilo je potrebno utvrditi psihometrijske karakteristike postojeće skale, primijenjene, kao i stabilnost faktorske strukture utvrđene, na uzorcima iz raznih populacija. Konačni cilj bio je utvrditi hijerarhiju vrijednosti i vrijednosne orijentacije reprezentativne podskupine srednjoškolaca srednjih strukovnih stručnih škola primorsko-goranske regije.

U istraživanju je sudjelovalo 760 sudionika deset srednjih stručnih škola u Rijeci i Opatiji (Tablica 1) prosječne dobi od 17,5 godina ( $\mathrm{SD}=1,22)$. Nešto su zastupljeniji muški ispitanici $(58,8 \%)$ i učenici nižih razreda srednje škole (55,5\% učenika prvog i drugog razreda). U uzorku ima najviše adolescenata u dobi starijeg maloljetništva, ali ih ima i jedna četvrtina u dobi mlađega punoljetništva, iz čega se može zaključiti da su utvrđene vrijednosne orijentacije osoba koje ili već jesu ili su uskoro kazneno-pravno odgovorne $\mathrm{u}$ društvu.

U izboru sudionika primijenjena je metoda grupnoga stratificiranog uzorka, i to tako da je iz svake škole odabran po jedan razred iz svake godine školovanja. Na taj je način u prikupljanju podataka sudjelovao po jedan razred u svakom obrazovnom razdoblju pojedine škole, bez obzira na to je li $u$ pitanju dvogodišnji, trogodišnji ili četverogodišnji program.

\begin{tabular}{lrr}
\hline Škola & $\mathrm{f}$ & $\%$ \\
\hline 1. Strojarsko-brodograđevna škola za industrijska i obrtnička zanimanja & 45 & 6 \\
2. Strojarska škola za industrijska i obrtnička zanimanja & 53 & 7 \\
3. Kemijsko-grafička škola & 79 & 10 \\
4. Ugostiteljska škola Opatija & 74 & 10 \\
5. Trgovačka i tekstilna škola & 93 & 12 \\
6. Ekonomska škola Mije Mirkovića & 87 & 12 \\
7. Obrtnička škola Opatija & 78 & 10 \\
8. Elektroindustrijska i obrtnička škola & 52 & 7 \\
9. Prometna škola & 92 & 12 \\
10. Srednja škola za elektrotehniku i računalstvo & 107 & 14 \\
Ukupno & 760 & 100 \\
\hline
\end{tabular}

\section{Postupak}

Podaci dobiveni za ovaj rad dio su prikupljanih podataka istraživačkoga projekta "Socijalni sukobi i razine poremećaja u ponašanju adolescenata". Prikupljani su u drugom polugodištu šk. god. 2007./2008. grupnim, anonimnim i dobrovoljnim anketiranjem srednjoškolaca, koji su ispunjavali anketni upitnik za vrijeme jednoga školskog sata. 


\section{Instrumentarii}

\section{Skala vrijednosnih orijentacija}

U istraživanju je uz pitanja o demografskim varijablama (spol i dob) upotrijebljena i skala vrijednosnih orijentacija. Autori skale (Franc i sur., 2002.) utvrdili su njezine metrijske karakteristike na reprezentativnom uzorku srednjoškolaca Republike Hrvatske $(\mathrm{N}=2823)$. Prema podacima navedenim u izvornom istraživanju, skala se sastoji od 18 čestica, koje se grupiraju u tri podskale nazvane samoostvarujuća (alpha $=0,75)$, konvencionalna (alpha $=0,75)$ i hedonistička vrijednosna orijentacija (alpha $=0,70)$. Autori su proveli analizu glavnih komponenata uz karakteristični korijen veći od jedan kao kriterij za zadržavanje značajnih komponenata i uz kosokutnu rotaciju komponenti. Tri značajne komponente objasnile su ukupno 47\% varijance rezultata skale. Rezultat na navedenim podskalama odredili su kao prosječnu procjenu važnosti sudionika na odgovarajućim česticama, tako da je rezultat mogao varirati u rasponu od 1 do 5 . Istovjetne nalaze autori su utvrdili i pri drugoj primjeni ove skale na reprezentativnom uzorku srednjoškolaca, pri čemu su rezultati na sve tri podskale ponovo imali zadovoljavajuće koeficijente unutarnje konzistencije ( $\mathrm{u}$ rasponu od 0,73 do 0,75, Ivičić, i sur., 2007.).

\section{REZULTATI}

\section{Provjera komponentne strukfure upitnika}

Kako bismo provjerili razlikuje li se komponentna struktura upitnika primijenjenog na uzorku učenika strukovnih srednjih škola od strukture dobivene na reprezentativnim uzorcima populacije učenika svih srednjih škola (Franc i sur., 2002.; Ivičić i sur., 2007.), na prikupljenim rezultatima ponovili smo eksploratornu komponentnu analizu. Rezultati su pokazali da četiri komponente imaju karakterističan korijen veći od $1 \mathrm{i}$ objašnjavaju ukupno 49,93\% varijance rezultata upitnika. Radi interpretacije dobivene komponentne strukture provedena je kosokutna rotacija komponentnih osi. Rezultati prikazani u matrici obrasca (Tablica 2) upućuju na zaključak da se komponentna struktura upitnika primijenjenog na učenike strukovnih srednjih škola znatno razlikuje od strukture koje su na reprezentativnim uzorcima svih učenika srednjih škola utvrdili autori skale.

U usporedbi s prethodnim nalazima, ovi rezultati pokazuju nešto složeniju komponentnu strukturu. Prema Tablici 4, izdvojene su četiri značajne komponente, koje se tek djelomično mogu povezati sa samoostvarujućom, konvencionalnom i hedonističkom vrijednosnom orijentacijom. Prvu komponentu čini kombinacija tvrdnji koje prema teorijskom okvi- 
(1) TABLICA 2

Matrica obrasca dobivena komponentnom analizom i kosokutnom rotacijom četiriju komponenata zadržanih prema kriteriju karakterističnoga korijena većeg od 1 ru pripadaju samoostvarujućoj (4 tvrdnje) i konvencionalnoj (4 tvrdnje) orijentaciji. Jedino se druga komponenta sastoji samo od tvrdnji koje pripadaju hedonističkoj orijentaciji (3 tvrdnje). Sadržaj tih tvrdnji uglavnom je vezan uz ugled, moć, utjecaj, zaradu i visok životni standard. Visoko zasićenje na trećoj komponenti ima kombinacija konvencionalnih (dvije tvrdnje) $\mathrm{i}$ jedne hedonističke tvrdnje sa sadržajem vezanim uz religiju, stabilnost, udobnost, izostanak konflikata i altruizam.

\begin{tabular}{lrrrr}
\hline Komponente & 1 & 2 & 3 & 4 \\
\hline 1. (S) Raditi ono što voliš i što ti omogućuje da stvaraš nešto novo & 0,714 & $-0,116$ & $-0,204$ & 0,092 \\
2. (K) Imati dobru naobrazbu i stjecati nova znanja & 0,707 & 0,168 & 0,047 & $-0,251$ \\
3. (S) Voljeti nekoga i biti voljen & 0,626 & 0,069 & $-0,023$ & 0,002 \\
4. (S) Ostvariti bliske, prijateljske odnose s drugim ljudima & 0,600 & $-0,090$ & 0,008 & 0,168 \\
5. (K) Biti pošten i živjeti u skladu sa svojim moralnim načelima & 0,560 & $-0,205$ & 0,377 & $-0,055$ \\
6. (S) Raditi nešto u čemu ćeš ostvariti svoje sposobnosti i interese & 0,552 & 0,055 & $-0,096$ & 0,254 \\
7. (K) Postići nešto po čemu ćeš dati vrijedan doprinos društvu & 0,516 & 0,280 & 0,212 & $-0,161$ \\
8. (K) Živjeti skladno u krugu svoje obitelji i prijatelja & 0,501 & $-0,038$ & 0,326 & 0,080 \\
9. (H) Biti ugledan i cijenjen u društvu & 0,102 & 0,746 & 0,072 & 0,017 \\
10. (H) Imati moć i mogućnost utjecaja na druge ljude & $-0,132$ & 0,744 & 0,022 & 0,055 \\
11. (H) Dobro zarađivati i imati visok životni standard & 0,150 & 0,632 & $-0,008$ & 0,198 \\
12. (K) Živjeti u skladu s učenjem svoje vjere & $-0,087$ & 0,166 & 0,800 & $-0,095$ \\
13. (H) Živjeti stabilno, udobno, bez većih trzavica & $-0,072$ & 0,023 & 0,599 & 0,476 \\
14. (K) Učiniti nešto za druge ljude, pomoći onima koji & & & \\
imaju problema & 0,421 & $-0,253$ & 0,512 & 0,080 \\
15. (H) Razonoditi se i zabavljati po volji & $-0,082$ & 0,154 & $-0,046$ & 0,716 \\
16. (S) Biti samostalan i nezavisan u svojim odlukama & 0,185 & $-0,138$ & 0,100 & 0,580 \\
17. (H) Imati lagodan život i nenaporan posao & $-0,059$ & 0,264 & 0,022 & 0,528 \\
18. (H) Doživjeti mnoga uzbuđenja & 0,247 & 0,189 & $-0,079$ & 0,363
\end{tabular}

Napomena: U zagradama su navedena početna slova faktora ( $\mathrm{S}=$ Samoostvarujuća; $\mathrm{K}=$ Konvencionalna i $\mathrm{H}=$ Hedonistička vrijednosna orijentacija) na kojima je tvrdnja imala najviše zasićenje u istraživanjima Francove i suradnika (Franc i sur., 2002.; Ivičić i sur., 2007.). Tvrdnje su poredane po veličini zasićenja na pripadajućem faktoru. Zasićenja veća od 0,300 su u kurzivu.

Zadnja, četvrta, komponenta jest kombinacija hedonističkih tvrdnji (tri tvrdnje) i jedne samoostvarujuće tvrdnje, a sadržajno se odnosi na razonodu, zabavu, samostalnost, komociju i traženje uzbudljivih situacija. Navedene empirijske komponente nisu dalje analizirane zbog nedostatnoga teorijskog okvira za formuliranje novih vrijednosnih orijentacija i zbog premaloga broja tvrdnji po komponenti, što je rezultiralo niskim pokazateljima pouzdanosti tipa unutarnje konzistencije. U idućem poglavlju raspravit ćemo moguća objašnjenja ovih rezultata i navesti preporuke za daljnje istraživanje.

Treba napomenuti da smo ponovili eksploratornu komponentnu analizu uz zadržavanje triju komponenti, s ciljem provjere trokomponentne strukture. Ni uz zadani broj komponenti čestice se nisu izdvojile prema teoriji u samoostvaru- 
DRUŠ. ISTRAŽ. ZAGREB GOD. 20 (2011), BR. 2 (112)

STR. $479-493$

VLAH, N., LONČARIĆ, D., TATALOVIĆ VORKAPIĆ, S.: STRUKTURA.. juću, konvencionalnu i hedonističku vrijednosnu orijentaciju. Visoka zasićenja na prvoj komponenti i dalje su imale u podjednakom broju samoostvarujuće i konvencionalne tvrdnje, druga komponenta bila je sastavljena isključivo od hedonističkih tvrdnji, a treća od jedne konvencionalne tvrdnje vezane uz religiju i jedne hedonističke vezane uz stabilnost, udobnost i izostanak konflikta. Nunnaly i Bernstein (1994.) navode da zadržane komponente $\mathrm{u}$ eksploratornoj komponentnoj analizi moraju objasniti barem $50 \%$ varijance rezultata upitni$\mathrm{ka}$, a navedena trokomponentna struktura objasnila je tek $43,60 \%$ varijance rezultata upitnika.

\section{Provjera faktorske strukture upitnika}

Analizu smo nastavili eksplorativnom provjerom faktorske strukture upitnika iz nekoliko razloga. Kaiser-Gutmannov kriterij zadržavanja komponenti ili faktora s karakterističnim korijenom većim od jedan često je kritiziran zbog mogućnosti hiperfaktorizacije i izdvajanja artificijelnih, neznačajnih i neinterpretabilnih faktora. Taj je kriterij primjeren eksploratornoj komponentnoj analizi, ali ne i eksploratornim faktorskim analizama. Te dvije analize imaju različite ciljeve i primjerene su različitim vrstama podataka. Komponentnom analizom nastojimo veći broj manifestnih varijabli svesti na što manji broj komponenti, uz zadržavanje što većega postotka ukupne varijance rezultata. Pri tome bismo morali pretpostaviti da primijenjene manifestne mjere nemaju pogrešku mjerenja, a tu je pretpostavku teško pravdati uz upotrebu upitničke metodologije u društvenim znanostima. $\mathrm{S}$ druge strane, cilj faktorske analize jest parcijalizirati varijancu rezultata na pravu varijancu (komunalitet i unikvitet) i varijancu pogreške. Pri tome je primjerenije rabiti druge kriterije značajnosti faktora, kao što je Cattellov (1966.) "Scree-test", koji je posebno pogodan ako želimo izbjeći probleme hiperfaktorizacije.

Kako bismo provjerili faktorsku strukturu upitnika, služili smo se eksploratornom faktorskom analizom uz "maximum likelihood" metodu ekstrakcije faktora. Broj značajnih faktora odredili smo Cattellovim kriterijem "Scree-testa" (Slika 2), a za postizanje Thurstonovih (1947.) kriterija jednostavne faktorske strukture proveli smo kosokutnu rotaciju faktorskih osi. Preliminarnom analizom utvrđeno je da dvije tvrdnje ("Živjeti stabilno, udobno, bez većih trzavica" i "Živjeti u skladu s učenjem svoje vjere") imaju visoke unikvitete, niske komunalitete te niska i teorijski nedosljedna zasićenja na izdvojenim faktorima. Te su tvrdnje izostavljene iz daljnje analize. Ispravnost takva postupka potvrđuje i činjenica da navedene tvrdnje smanjuju pouzdanost tipa unutarnje konzistencije ako se 
DRUŠ. ISTRAŽ. ZAGREB GOD. 20 (2011), BR. 2 (112)

STR. 479-493

VLAH, N., LONČARIĆ, D. TATALOVIĆ VORKAPIC, $S$. STRUKTURA...

\section{- SLIKA 2}

Cattellov "Scree-test" upotrijeblien za određivanje broja značajnih faktora $u$ faktorskoi analizi

(1) TABLICA 3

Matrica obrasca dobivena fakłorskom analizom i kosokutnom rotacijom dvaju faktora zadržanih

prema kriteriju

Cattellova "Scree-testa" lizom provedenom na preostalih 16 tvrdnji izdvojena su dva značajna faktora koja objašnjavaju $31,11 \%$ varijance rezultata upitnika.

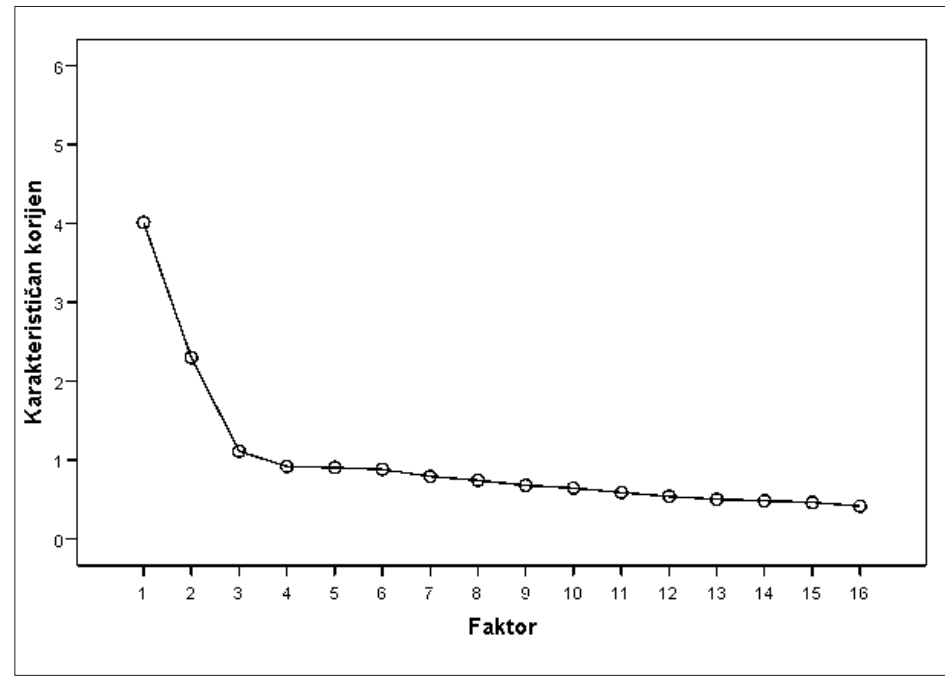

Iz Tablice 3 vidi se da visoka zasićenja na prvom faktoru imaju sve tvrdnje koje prema teoriji odražavaju samoostvarujuću i konvencionalnu vrijednosnu orijentaciju, a visoka zasićenja na drugom faktoru imaju samo tvrdnje koje odražavaju hedonističku vrijednosnu orijentaciju.

Faktor (vrijednosna orijentacija)

1. Konvencionalna

i samoostvarujuća 2. Hedonistička

(K) Biti pošten i živjeti u skladu sa svojim moralnim načelima

(K) Učiniti nešto za druge ljude, pomoći onima koji imaju problema

(K) Živjeti skladno u krugu svoje obitelji i prijatelja

(S) Ostvariti bliske, prijateljske odnose s drugim ljudima

(K) Imati dobru naobrazbu i stjecati nova znanja

(S) Raditi ono što voliš i što ti omogućuje da stvaraš nešto novo

(S) Voljeti nekoga i biti voljen

(K) Postići nešto čime ćeš dati vrijedan doprinos društvu

(S) Raditi nešto u čemu ćeš ostvariti svoje sposobnosti i interese

(S) Biti samostalan i nezavisan u svojim odlukama

(H) Imati moć i mogućnost utjecaja na druge ljude

$(\mathrm{H})$ Dobro zarađivati i imati visok životni standard

(H) Biti ugledan i cijenjen u društvu

(H) Razonoditi se i zabavljati po volji

(H) Imati lagodan život i nenaporan posao

(H) Doživjeti mnoga uzbuđenja

$\begin{array}{rr}0,729 & -0,220 \\ 0,677 & -0,185 \\ 0,622 & 0,004 \\ 0,559 & 0,022 \\ 0,556 & 0,006 \\ 0,534 & -0,024 \\ 0,517 & 0,058 \\ 0,468 & 0,126 \\ 0,462 & 0,182 \\ 0,314 & 0,183 \\ -0,200 & 0,621 \\ 0,068 & 0,616 \\ 0,031 & 0,600 \\ 0,014 & 0,472 \\ 0,023 & 0,446 \\ 0,206 & 0,323\end{array}$

Napomena: Tvrdnje su poredane po veličini zasićenja na pripadajućem faktoru. Zasićenja veća od 0,300 su u kurzivu. 
DRUŠ. ISTRAŽ. ZAGREB GOD. 20 (2011), BR. 2 (112)

STR. $479-493$

VLAH, N., LONČARIĆ, D., TATALOVIĆ VORKAPIĆ, S.: STRUKTURA
Stoga su faktori i s njima povezane podskale nazvani samoostvarujuća i konvencionalna vrijednosna orijentacija i hedonistička vrijednosna orijentacija. Ipak, nekoliko pokazatelja sugerira da su pitanja u izvornom upitniku nešto heterogenija u odnosu na predloženu dvofaktorsku strukturu. Prvi pokazatelj odnosi se na odluku da izostavimo neke tvrdnje iz provjere faktorske strukture na temelju visokih unikviteta i niskih komunaliteta i faktorskih zasićenja. Te tvrdnje mogu biti manifesti nekoga drugog faktora vezanog npr. uz religijske vrijednosne orijentacije. Također, postotak objašnjene varijance nije ni blizu poželjne granice od $40 \%$ za faktorsku analizu (Nunnaly i Bernstein, 1994.), što također sugerira postojanje dodatnih faktora. Iz Slike 2 ipak se vidi da zadržavanje dodatnih faktora ne bi znatnije pridonijelo povećanju objašnjene varijance rezultata u upitniku. To upućuje na ćinjenicu da su eventualni dodatni faktori povezani s malim brojem manifestnih varijabli, kojima tek treba dati jedinstven teorijski okvir.

\section{Hijerarhija vrijednosti i vrijednosnih orijentacija}

Završni cilj ovog rada bio je utvrditi hijerarhiju vrijednosti i vrijednosnih orijentacija učenika srednjih strukovnih škola. Prethodne analize pokazale su da učenici strukovnih škola ne diferenciraju samoostvarujuću orijentaciju od konvencionalne vrijednosne orijentacije te da bi bilo primjereno te dvije vrijednosne orijentacije mjeriti jednom podskalom, a hedonističku vrijednosnu orijentaciju drugom podskalom. Ipak, iz teorijskih razloga i zbog mogućnosti usporedbe rezultata s prethodnim istraživanjima, zadržali smo i podjelu na samoostvarujuću i konvencionalnu vrijednosnu orijentaciju.
Deskriptivni parametri, pouzdanost i interkorelacije podskala vrijednosnih orijentacija
Korelacije

\begin{tabular}{rrrrrr} 
& & \multicolumn{3}{c}{ Korelacije } \\
\cline { 3 - 6 } M & SD & Alpha & 1. & 2. & 3. \\
\hline 4,500 & 0,509 & 0,647 & 1 & & \\
4,045 & 0,636 & 0,710 & 0,552 & 1 & 1 \\
4,273 & 0,505 & 0,786 & 0,851 & 0,907 & 0,278 \\
3,914 & 0,607 & 0,689 & 0,300 & 0,201 & 0,27
\end{tabular}

Napomena: Rezultat na podskalama podijeljen je s brojem tvrdnji radi usporedivosti i svođenja raspona na vrijednosti između 1 i 5 . Sukladno rezultatima u Tablicama 4 i 5 iz konvencionalne te konvencionalne i samoostvarujuće podskale izostavljena je čestica $12 \mathrm{~K}$, a iz hedonističke tvrdnja $13 \mathrm{H}$. Sve navedene korelacije statistički su značajne na razini $p<0,01$.

Iz Tablice 4 vidi se da skupna samoostvarujuća i konvencionalna vrijednosna orijentacija ima najviši koeficijent pouzdanosti, zasebna konvencionalna i zasebna hedonistička vrijednosna orijentacija nešto niži, a zasebna samoostvarujuća vrijednosna orijentacija ima najniži koeficijent pouzdanosti. I ti pokazatelji upućuju na potrebu dogradnje i rekonstrukcije ovog upitnika pri primjeni u stručnim srednjim školama. 
DRUŠ. ISTRAŽ. ZAGREB GOD. 20 (2011), BR. 2 (112),

STR. $479-493$

VLAH, N., LONČARIĆ, D., TATALOVIĆ VORKAPIC, S.: STRUKTURA

(1) TABLICA 5

Hijerarhija vrijednosti učenika strukovnih srednjih škola
Pozitivne korelacije među svim podskalama upućuju na zajednički izvor svih vrijednosnih orijentacija, ali visina povezanosti znatno varira. Samoostvarujuća i konvencionalna vrijednosna orijentacija znatno su povezanije, što pokazuje da učenici koji imaju jednu vrijednosnu orijentaciju uglavnom imaju i drugu, i obratno. S druge strane, hedonistička vrijednosna orijentacija ima znatno niže koeficijente korelacije s preostale dvije ili sa zbirnom samoostvarujuće-konvencionalnom vrijednosnom orijentacijom, sugerirajući da učenici koji su uglavnom hedonistički orijentirani mogu, ali i ne moraju, imati visok rezultat na preostalim vrijednosnim orijentacijama.

Oko hijerarhije vrijednosnih orijentacija (Tablica 5), učenici samoiskazom daju znatnu prednost samoostvarujućoj vrijednosnoj orijentaciji, u nešto manjoj mjeri iskazuju konvencionalnu vrijednosnu orijentaciju (skupna samoostvarujuće-konvencionalna vrijednosna orijentacija ima rezultat između navedenih vrijednosti), a najmanje ih karakterizira hedonistička vrijednosna orijentacija.

U vezi s hijerarhijom vrijednosti, u samom je vrhu ljubav, skladan život, obitelj, prijatelji i bliski prijateljski odnosi, dok su na samom dnu liste moć, mogućnost utjecaja i život u skladu s učenjem vlastite vjere.

\begin{tabular}{lrr}
\hline & M & SD \\
\hline 1. (S) Voljeti nekoga i biti voljen & 4,64 & 0,762 \\
2. (K) Živjeti skladno u krugu svoje obitelji i prijatelja & 4,56 & 0,773 \\
3. (S) Ostvariti bliske, prijateljske odnose s drugim ljudima & 4,52 & 0,738 \\
4. (S) Raditi ono što voliš i što ti omogućuje da stvaraš nešto novo & 4,49 & 0,837 \\
5. (S) Biti samostalan i nezavisan u svojim odlukama & 4,45 & 0,831 \\
6. (S) Raditi nešto u čemu ćeš ostvariti svoje sposobnosti i interese & 4,41 & 0,780 \\
7. (K) Učiniti nešto za druge ljude, pomoći onima koji imaju problema & 4,28 & 0,896 \\
8. (K) Biti pošten i živjeti u skladu sa svojim moralnim načelima & 4,26 & 0,961 \\
9. (H) Dobro zarađivati i imati visok životni standard & 4,21 & 0,908 \\
10. (K) Imati dobru naobrazbu i stjecati nova znanja & 4,19 & 0,910 \\
11. (H) Doživjeti mnoga uzbuđenja & 4,18 & 0,872 \\
12. (H) Živjeti stabilno, udobno, bez većih trzavica & 4,14 & 0,914 \\
13. (H) Imati lagodan život i nenaporan posao & 4,12 & 1,024 \\
14. (H) Razonoditi se i zabavljati po volji & 4,10 & 0,975 \\
15. (K) Postići nešto po čemu ćeš dati vrijedan doprinos društvu & 3,85 & 1,031 \\
16. (H) Biti ugledan i cijenjen u društvu & 3,69 & 1,161 \\
17. (K) Živjeti u skladu s učenjem svoje vjere & 3,14 & 1,315 \\
18. (H) Imati moć i mogućnost utjecaja na druge ljude & 2,97 & 1,284
\end{tabular}

Napomena: Tvrdnje su poredane po rangu rezultata od tvrdnje s najvećim prosjekom odgovora do tvrdnje s najmanjim prosjekom odgovora na skali Likertova tipa.

\section{RASPRAVA I ZAKLJUČAK}

Iz rezultata eksploratorne komponentne analize možemo izvesti nekoliko važnih zaključaka. Komponentna struktura upitnika primijenjenog na učenicima strukovnih škola znat- 
DRUŠ. ISTRAŽ. ZAGREB GOD. 20 (2011), BR. 2 (112)

STR. $479-493$

VLAH, N., LONČARIĆ, D., TATALOVIĆ VORKAPIĆ, S.: STRUKTURA. i suradnika (2002.). S jedne strane, veći broj faktora upućuje na finiju diferencijaciju vrijednosnih orijentacija. $S$ druge strane, raspored tvrdnji po komponentama sugerira da učenici strukovnih škola ne diferenciraju samoostvarujuću i konvencionalnu orijentaciju. Umjesto navedene podjele, učenici uz konglomerat samoostvarujuće i konvencionalne orijentacije diferenciraju još i religijske, pacifističke i altruističke vrijednosti te vrijednosti u čijoj je osnovi zabava, autonomija i uzbuđenje. S obzirom na to da se zbog maloga broja tvrdnji nisu mogle konstruirati pouzdane skale, možemo samo pretpostaviti da učenici srednjih strukovnih škola posebnu važnost pripisuju diferencijaciji navedenih vrijednosti. Ubuduće bi trebalo provjeriti teorijsku utemeljenost takve empirijske diferencijacije, nakon čega bi se skala mogla proširiti dodatnim tvrdnjama, s ciljem pouzdana i valjana mjerenja novih vrijednosnih orijentacija.

Eksploratorna faktorska analiza dala je dodatnu podršku spajanju samoostvarujuće i konvencionalne vrijednosne orijentacije i njihovu razlikovanju od hedonističke vrijednosne orijentacije. Ipak, neki pokazatelji, poput tvrdnji o visokom unikvitetu, niskom komunalitetu i faktorskim zasićenjima te malenom postotku objašnjene varijance rezultata upitnika, upućuju na potrebu daljnjeg razvoja skale u smjeru identifikacije novih vrijednosnih orijentacija koje bi obuhvaćale religijske vrijednosti. Eksploratorna komponentna analiza pokazala je i da se na uzorku učenika strukovnih škola mogu diferencirati i specifične ležerne hedonističke vrijednosti usmjerene na autonomiju, zabavu, komfor i izazove, što možemo lako razlikovati od aktivnih hedonističkih vrijednosti s karakterom imperativa i dominacije, poput ugleda, moći, utjecaja, zarade i standarda.

Prema Maslowljevoj humanističkoj teoriji, samoaktualizacija je na vrhu hijerarhije motivacijskih vrijednosti. Budući da je ovdje riječ o učenicima strukovnih škola, koji su u odnosu na osnovnoškolski uspjeh bili nižih uspjeha od svojih vršnjaka koji su pohađali gimnazije, a koji nisu ispitivani u ovom istraživanju, moguće je da se kod naših sudionika razina samoaktualizacije, shvaćena prema Maslowljevoj teoriji, odvija paralelno s ispunjavanjem konvencionalnih očekivanja i konformizmom prema izvanjskim tradicionalnim zahtjevima društva. Ovu bi pretpostavku valjalo dodatno istražiti analizom latentne strukture odnosa između ciljnih i vrijednosnih orijentacija na različitim poduzorcima. Opravdanost pretpostavke da su srednje stručne škole specifične po obilježjima ponašanja svojih učenika potvrđuje istraživanje Bouillet i suradnika (2005.), prema kojemu se među osnovnim školama i gimnazijama, po raznolikosti i učestalosti nasilničkoga ponašanja, ističu stručne četverogodišnje i trogodišnje škole. 
DRUŠ. ISTRAŽ. ZAGREB GOD. 20 (2011) BR. 2 (112)

STR. $479-493$

VLAH, N., LONČARIĆ, D. TATALOVIĆ VORKAPIC, $S$. STRUKTURA

Razlike u komponentnoj i faktorskoj strukturi, koje su utvrđene eksplorativnim metodama, te $u$ vrijednosnoj hijerarhiji mogu biti povezane i sa strukturom uzorka (reprezentativan uzorak populacije svih učenika i uzorak učenika strukovnih škola) i s generacijskim promjenama koje su se zbile između dva istraživanja (efekt kohorte). Za pouzdanije zaključke o eventualnim specifičnostima vrijednosne hijerarhije učenika strukovnih škola u odnosu na populaciju srednjoškolskih učenika trebalo bi provesti ispitivanje uzorka populacije i uzorka učenika strukovnih škola u istoj generaciji. Isto tako, za pouzdanije zaključke o generacijskim promjenama rezultati bi morali biti prikupljeni na usporedivim uzorcima učenika različitih generacija. $U$ daljnjim istraživanjima bilo bi vrijedno i longitudinalno pratiti razvojne promjene u vrijednosnoj strukturi i hijerarhiji učenika u dužem razdoblju mladenaštva i ranoj odrasloj dobi.

\section{LITERATURA}

Ajduković, M. (1989.), Vrijednosne orijentacije maloljetnih delikvenata, Zagreb: Narodne novine i Pravni fakultet u Zagrebu.

Bouillet, D., Uzelac, S. i Kapac, V. (2005.), Iskaz razrednika o nasilničkom ponašanju u hrvatskim školama. Napredak, 146 (2): 170-183.

Braithwaite, V. A. i Scott, W. A. (1991.), Values. U: J. P. Robinson, P. R. Shaver i L. S. Wrightsman (ur.), Measures of Personality and Social Psychology Attitudes (str. 661-753), New York: Academic Press.

Cattell, R. B. (1966.), The Scree Test for the Number of Factors. Multivariate Behavioral Research, 1 (2): 245-276. doi:10.1207/s15327906 mbr0102 10

Čulig, B., Fanuko, N. i Jerbić, V. (1982.), Vrijednosti i vrijednosne origodine, Zagreb: Centar društvenih djelatnosti Saveza Socijalističke omladine Hrvatske.

Franc, R., Šakić, V. i Ivičić, I. (2002.), Vrednote i vrijednosne orijentacije adolescenata: Hijerarhija i povezanost sa stavovima i ponašanjima. Društvena istraživanja, 11 (2-3): 215-238.

Homer, P. M. i Kahle, L. R. (1988.), A Structural Equation Test for the Value-Attitude-Behavior Hierarchy. Journal of Personality and Social Psychology, 54 (4): 638-646. doi:10.1037//0022-3514.54.4.638

Ivičić, I., Franc, R. i Šakić, V. (2007.), Stability and Change in Value Priorities among Croatian Adolescents (poster prezentacija)// X European Congress of Psychology - ECP2007 - Abstracts / Kotrlova, Jindriska (ur.). Prag: Union of Psychologists Associations of the Czech Republic, 2007. Poster je dostupan na http://bib.irb.hr/datoteka/ 317637.poster1_1_1.pdf

Mandarić, V. B. (2000.), Religiozni identitet zagrebačkih adolescenata, Zagreb: Institut društvenih znanosti Ivo Pilar i Katolički bogoslovni fakultet.

Mayton, D. M., Ball-Rokeach, S. J. i Loges, W. E. (1994.), Human Values and Social Issues: An Introduction. Journal of Social Issues, 50 (4): 1-8. doi:10.1111/j.1540-4560.1994.tb01194.x jentacije mladih. Rezultati istraživanja provedenog u SR Hrvatskoj 1981. 
DRUŠ. ISTRAŽ. ZAGREB GOD. 20 (2011), BR. 2 (112)

STR. $479-493$

VLAH, N., LONČARIĆ, D., TATALOVIĆ VORKAPIĆ, S.: STRUKTURA.
Nunnaly, J. i Bernstein, I. (1994.), Psychometric Theory, New York: McGraw-Hill.

Pennington, D. C. (1997.), Osnove socijalne psihologije, Jastrebarsko: Naklada Slap.

Radin, F. (1988.), Hijerarhije i strukture društvenih vrijednosti. U: N. Fanuko, V. Ilišin, D. Marinović, V. Obradović, M. Oliveria-Roca, F. Radin, I. Rimac, H. Štimac i S. Vrcan, Fragmenti omladine (str. 99-118), Zagreb: Radna zajednica RK SSOH i Institut za društvena istraživanja Sveučilišta u Zagrebu.

Radin, F. (1990.), Sustavi vrijednosti. U: V. Ilišin, F. Radin, H. Štimac i S. Vrcan, Ogledi o omladini osamdesetih (str. 21-60), Zagreb: Institut za društvena istraživanja Sveučilišta u Zagrebu.

Radin, F. (2002.), Vrijednosne hijerarhije i strukture. U: V. Ilišin i F. Radin (ur.), Mladi uoči trećeg milenija (str. 47-78), Zagreb: Institut za društvena istraživanja, Državni zavod za zaštitu obitelji, materinstva i mladeži.

Rohan, M. J. i Zanna, M. P. (2001.), Values and Ideologies. U: A. Tesser i N. Schwartz (ur.), Blackwell Handbook of Social Psychology: Intraindividual Processes (Vol. 1), Oxford, England: Blackwell.

Rokeach, M. (1973.), The Nature of Human Values, New York: Free Press.

Rokeach, M. (1979.), Understanding Human Values: Individual and Societal, New York: Free Press

Rokeach, M. (1982.), Value Survey, Palo Alto, CA: Consulting Psychologists Press.

Rokeach, M. i Ball-Rokeach, S. J. (1989.), Stability and Change in American Value Priorities, 1968-1981. American Psychologist, 44 (5): 775-784. doi:10.1037/0003-066X.44.5.775

Romero, E., Sobral, J., Luengo, M. A. i Marzoa, J. A. (2001.), Values and Antisocial Behaviour among Spanish Adolescents. Journal of Genetic Psychology, 162 (1): 20-40. doi:10.1080/00221320109597879

Schwartz, S. H. (1994.), Are There Universal Aspects in the Structure and Contents of Human Values? Journal of Social Issues, 50 (4): 19-45. doi:10.1111/j.1540-4560.1994.tb01196.x

Schwartz, S. H. (1996.), Value Priorities and Behaviour: Applying a Theory of Integrated Value Systems. U: C. Seligman, J. M. Olson i M. P. Zanna (ur.), The Psychology of Values: The Ontario Symposium (str. 1-24), Vol. 8. Manhwah, New Jersey: LEA.

Schwartz, S. H. (1999.), A Theory of Cultural Valued and Some Implications for Work. Applied Psychology, An International Review, Special Review.

Schwartz, S. H. (2006.), Value Orientations: Measurement, Antecedents and Consequences across Nations. U: R. Jowell, C. Roberts, R. Fitzgerald i G. Eva (ur.), Measuring Attitudes Cross-Nationally - Lessons From the European Social Survey. London: Sage.

Schwartz, S. H. i Bilsky, W. (1987.), Toward a Universal Psychological Structure of Human Values. Journal of Personality and Social Psychology, 53 (3): 550-562. doi:10.1037/0022-3514.53.3.550

Schwartz, S. H. i Bilsky, W. (1990.), Toward a Theory of the Universal Content and Structure of Values: Extensions and Cross Cultural 
DRUŠ. ISTRAŽ. ZAGREB GOD. 20 (2011)

BR. 2 (112)

STR. 479-493

VLAH, N., LONČARIĆ, D. TATALOVIĆ VORKAPIĆ, S. STRUKTURA.
Replications. Journal of Personality and Social Psychology, 58 (5): 878-891. doi:10.1037//0022-3514.58.5.878

Seligman, C., Olson, J. M. i Zanna, M. P. (1996.), The Psychology of Values: The Ontario Symposium, Vol. 8. Manhwah, New Jersey: LEA.

Thurstone, L. L. (1947.), Multiple Factor Analysis, Chicago: University of Chicago Press.

Ule, M., Rener, T., Čeplak, M. M. i Tivadar, B. (2000.), Socialna ranjivost mladih, Ljubljana: Ministarstvo za školstvo in šport, Urad Republike Slovenije za mladino in Založba Aristej.

\section{Structure and Hierarchy of Vocational School Students' Value Orientations}

Nataša VLAH

Kindergarten Rijeka, Rijeka

Darko LONČARIĆ, Sanja TATALOVIĆ VORKAPIĆ

Faculty of Teacher Education, Rijeka

Drawing on the previous research of the hierarchy of values and representation of value orientations of adolescents, we have defined two research goals: (1) to determine the value orientations of the representative subgroup of vocational school students in Primorsko Goranska County, and (2) to make a contribution to the research of factor structure and scale reliability of the Values Orientation Scale (Franc et al., 2002) on the same sample. The data were collected from a stratified group sample of 760 students $(M=17.5$ years; $\mathrm{SD}=1.22 ; 41.2 \%$ female students) attending ten different vocational schools. The aim was to verify the component and factor structure of the scale and its reliability as well as to determine the students' hierarchy of values and value orientations. The results indicate that the component structure of the questionnaire that was applied on the vocational schools students differs significantly from the structure on the representative sample of the students of all high schools determined by the authors of the scales. By way of factor analysis, two significant factors were extracted: (1) self-realization and conventional value orientation and (2) hedonistic value orientation. Love, balanced life style, family, friends, and close friendships are at the top of the students' hierarchy of values. The results imply the need to upgrade and reconstruct this scale for further application in vocational schools.

Keywords: value orientations, vocational school students 
DRUŠ. ISTRAŽ. ZAGREB GOD. 20 (2011), BR. 2 (112)

STR. $479-493$

VLAH, N., LONČARIĆ, D., TATALOVIĆ VORKAPIĆ, S.: STRUKTURA.

\section{Struktur von Wertorientierungen und Wertehierarchie bei Berufsschülern}

\author{
Nataša VLAH \\ Kindergarten Rijeka, Rijeka \\ Darko LONČARIĆ, Sanja TATALOVIĆ VORKAPIĆ \\ Fakultät für Lehrerbildung, Rijeka
}

In Anlehnung an vorhergehende Untersuchungen zur Wertehierarchie und zur Präsenz von Wertorientierungen unter Jugendlichen hatten sich die Verfasser dieser Studie zwei Ziele gestellt: (1) die Ermittlung von Wertorientierungen bei einer repräsentativen Gruppe von Berufsschülern der nordwestkroatischen Region Primorsko-Goranska und (2) ein Beitrag zur Erforschung der Faktorenstruktur und der Verlässlichkeit der Wertorientierungsskala (nach Franc et al., 2002), die bei der genannten Untersuchungsgruppe zur Anwendung kam. An der Untersuchung nahmen 760 Schüler $(M=17,5$ Jahre; $S D=1,22 ;$ Schülerinnenanteil: 41,2\%) aus zehn verschiedenen Berufsschulen teil. Die Komponenten- und Faktorenstruktur sowie die Verlässlichkeit der angewandten Wertorientierungsskala wurden geprüft und die bestehende Wertehierarchie sowie

Wertorientierungen wurden ermittelt. Die Ergebnisse zeigen, dass die Komponentenstruktur des unter den befragten Berufsschülern angewandten Fragebogens deutlich abweicht von der Komponentenstruktur, die von denselben Autoren in einer repräsentativen Umfrage unter Schülern der übrigen kroatischen Mittelschulen ermittelt wurde. Anhand einer Faktorenanalyse konnten zwei wichtige Faktoren bestimmt werden: (1) das Bestehen einer konventionellen, auf die Selbstverwirklichung abzielenden Orientierung und (2) das Bestehen einer hedonistischen Wertorientierung. Die führenden Werte nach Meinung der befragten Schüler sind: Liebe, harmonische Lebensführung, Familie, Freunde und enge freundschaftliche Beziehungen. Die Verfasser der Studie verweisen auf die Notwendigkeit, den angewandten Fragebogen auszubauen und zu rekonstruieren, um ihn auf den Einsatz in Berufsschulen zuzuschneiden.

Schlüsselbegriffe: Wertorientierungen, Berufsschüler 